\title{
ANALISIS FAKTOR YANG MEMPENGARUHI TIDAK ADANYA PERKARA EKONOMI SYARIAH MASUK DI PENGADILAN AGAMA SINGARAJA
}

\author{
Iqbal Kadafi \\ Dian Berkah
}

e-mail: abdi.iqbal.kadafi@gmail.com

\begin{abstract}
By a implementation of Law No.3, 2006 which is a revision of Law No.7, 1989 concerns with Religious Courts which is reinforced by Constitutional Court decision Number : 93/PUU-X/2012, on 29 Agustus 2013 judicial review cases toward a regulation section 55, article 2 of Law no 21, 2008 about Sharia Banking, it means that the position of Religious Courts increasingly strong and clear. This is in line with the increasing absolute authority of Religious Courts, especially in handling sharia economic cases.

The authority of the Religious Courts in the field of Islamic economics already covers the entire field of sharia economy and business activities of sharia economy, which basically was born because of a contract or agreement based on sharia principles.

Singaraja which is the capital of Buleleng Regency is located at Ujung Utara Island Bali Province whose majority of the population is Hindu and their economic activity uses sharia akad, or it is often mixed between sharia system with local legal culture of Singaraja people who tend to avoid contact with law and court so that it is rarely even there is no issue concerning with sharia economy into the Religious Court of Singaraja.

Nevertheless, the Religious Court of Singaraja must prepare itself by building a reliable and professional human resources if the case of sharia economic will be entered anytime there.
\end{abstract}

Keywords: Authority of Religious Courts and Issues of Sharia Economics in minority areas

\section{A. PENDAHULUAN}

Ekonomi syariah adalah satu kesatuan tak terpisahkan dengan ajaran Islam yang komprehensif dan universal, sifat dan cakupannya yang luas serta fleksibel khususnya di bidang mu'amalah sehingga dapat diterapkan pada setiap komunitas termasuk non muslim. ${ }^{1}$ Secara historis eksistensi ekonomi syariah telah ada dan dipraktikkan sejak eksisnya Islam di Nusantara. Sedangkan secara yuridis formal ekonomi syariah diakui sejak 26

1 Muhammad Syafi'i Antonio, Bank Syari'ah, Cet. 1, Gema Insani, Jakarta, 2001, hlm.4 
tahun silam, ditandai dengan berdirinya Bank Muamalah Indonesia tanggal 1 Mei 1992, merupakan Bank Islam pertama di Indonesia berbasis syariah sebagai salah satu bagian dari lembaga pengelola kegiatan ekonomi syariah.

Ekonomi syariah di Indonesia tergolong relatif baru, dibandingkan dengan industri-industri keuangan dan bisnis konvensional. Baru, tetapi dalam waktu yang relatif singkat, ia tumbuh dan berkembang sangat pesat, dan pada saat ini telah menjadi bagian terpenting dan strategis sebagai salah satu motor penggerak roda perekonomian Indonesia. $^{2}$

Pertumbuhan dan perkembangan ekonomi syariah di Indonesia tidak hanya disektor bisnis financial atau perbankan, termasuk ragam dan jenis kegiatan ekonomi syariah mulai bermunculan seperti asuransi syariah, pegadaian syariah. Dengan demikian ekonomi syariah telah menjadi bagian integral terhadap pembangunan ekonomi Indonesia yang terbukti mampu bertahan di tengah perekonomian dunia sedang mengalami gejolak.

Dengan semakin luas dan beragamnya pola bisnis berbasis ekonomi syariah, maka aspek perlindungan dan kepastian hukum dalam penerapan asas perjanjian

2 Adiwarman A. Karim, Perkembangan Ekonomi Syariah dan Potensi Sengketanya di Peradilan Agama Majalah Peradilan Agama, Edisi 3, Des 2013-Feb 2014, Penerbit Dirjen Badilag MA-RI, 2013, hlm.5 dalam akad atau kontrak di setiap Lembaga dan transaksi ekonomi Syariah menjadi sangat urgen diupayakan implementasinya. Karena pada tataran pelaksanaan transaksi bisnis ekonomi Syariah tidak menutup kemungkinan terjadinya penyimpanganpenyimpangan dari kesepakatan yang telah dibuat oleh kedua belah pihak. Sehingga dalam koridor masyarakat yang sadar hukum, tidak dapat dihindari munculnya perilaku saling tuntut menuntut satu sama lain, yang mengakibatkan kuantitas dan kompleksitas perkara-perkara bisnis syariah akan sangat tinggi dan beragam.

Kekuasaan Peradilan Agama berdasarkan Undang-Undang Nomor 3 tahun 2006 lebih luas dari pada Undang-undang Nomor 7 tahun 1989. Peradilan Agama sebagai salah satu pelaku kekuasaan kehakiman bertugas menyelenggarakan penegakan hukum dan keadilan bagi rakyat pencari keadilan perkara tertentu, antar orang yang beragama Islam dalam bidang perkawinan, waris, wasiat, hibah, wakaf, zakat, infaq, shadaqah, dan ekonomi syariah. Landasan hukum positif penerapan hukum Islam diharapkan lebih kokoh dengan Undang-undang Nomor 3 Tahun 2006 ini, karena telah menghapus permasalahan pilihan hukum ${ }^{3}$

Perluasan kewenangan

Pengadilan Agama (PA) disesuaikan dengan perkembangan hukum dan

\footnotetext{
3 Afdol, Legislasi Hukum Islam di Indonesia, (Surabaya: Airlangga University Press, 2006), hlm. 119
} 
kebutuhan hukum masyarakat. Perluasan tersebut meliputi bidang ekonomi syariah. Di dalam Undangundang Nomor 7 Tahun 1992 tentang perbankan sebagaimana telah diubah dengan Undang-undang Nomor 10 Tahun 1998 antara lain diatur tentang pembiayaan berdasarkan prinsip syariah.

Prinsip syariah yang dimaksud adalah aturan perjanjian berdasarkan hukum Islam antara pihak bank dan pihak untuk penyimpanan dana dan pembiayaan kegiatan usaha atau kegiatan lain, yang dinyatakan sesuai dengan syariah antara lain mudharabah, musyarakah dan murabahah. ${ }^{4}$

Dengan berlakunya UndangUndang Nomor 3 Tahun 2006 kedudukan Badan Peradilan Agama semakin eksis. Hal ini seiring bertambahnya kewenangan absolut Peradilan Agama dalam menangani sengketa ekonomi syariah, ini menunjukan bahwa Peradilan Agama semakin mendapatkan kepercayaan masyarakat dan negara Indonesia untuk mengadili dan menyelesaikan perkaraperkara terutama masalah sengketea ekonomi syariah.

Adapun yang dimaksud dengan ekonomi syariah adalah perbuatan atau kegiatan usaha yang dilaksanakan menurut prinsip syariah, meliputi Bank Syariah, Asuransi Syariah, Reasuransi, Reksadana Syariah, Obligasi Syariah dan surat berharga berjangka menengah syariah, Sekuritas Syariah,

4 Mohammad Daud Ali, Lembaga-lembaga Islam di Indonesia, (Jakarta: Raja Grafindo, 1995), hlm 119
Pegadaian syariah, Dana Pensiun Lembaga Keuangan Syariah dan Lembaga Keuangan Mikro-Syariah. ${ }^{5}$

Kewenangan mengadili lingkungan Peradilan Agama dalam bidang ekonomi syariah sudah meliputi keseluruhan bidang ekonomi syariah. Hal ini dapat dipahami dari maksud kata ekonomi syariah itu sendiri yang dalam penjelasan dalam pasal tersebut diartikan sebagai perbuatan atau kegiatan usaha yang dilaksanakan menurut prinsip syariah. Artinya, seluruh perbuatan atau kegiatan apa saja dalam bidang ekonomi yang dilakukan menurut prinsip syariah ia termasuk dalam jangkauan kewenangan mengadili lingkungan Peradilan Agama.

Kehadiran undang-undang Nomor 3 Tahun 2006 tentang peradilan agama pada saat itu belum bisa menjawab sepenuhnya perihal penyelesaian sengketa ekonomi syariah, karena masih banyak penyelesaian sengketa diselesaikan melalui pengadilan negeri, terlebih lagi ketika muncul Undang-undang Nomor 21 Tahun 2008 tentang perbangkan syariah terutama pada Pasal 55, dimana terdapat pasal yang bertentangan antara satu dengan yang lainnya di dalam pasal tersebut, dan bertentangan pula dengan Ketentuan Undang-undang No. 3 Tahun 2006.

Munculnya Undang-undang No. 21 Tahun 2008 khususnya Pasal 55 ayat 2 memunculkan polemik baru mengenai siapa yang berwenang untuk menyelesaikan sengketa ekonomi

\footnotetext{
5 Mardani, Hukum Acara Peradilan Agama, (Jakarta: Sinar Grafika, 2007), hlm. 58.
} 
syariah, apakah menjadi kewenangan Pengadilan Agama atau pengadilan Negeri.

Terhadap polemik tersebut
akhirnya sebagain masyarakat
mengujikan pasal tersebut ke
mahkamah konstitusi yang akhirnya
melahirkan putusan Mahkamah
Konstitusi Nomor : 93/PUU- X/2012, tanggal 29 Agustus 2013 sebagai penjelasan akhir terhadap polemik tersebut, yang pada pokoknya penyelesaian sengketa ekonomi syariah tersebut menjadi kewenangan absolut pengadilan agama sepanjang tidak ditentuan penyelesaiannya melalu badan arbitrase.

Hal ini juga sekaligus dapat merubah pemahaman masyarakat akan pengadilan agama sebagai "pengadilan cerai", dimana pengadilan agama hanya bisa menyelesaiakan urusan masalah perceraian saja. Padahal mengenai kewenangan Pengadilan Agama sudah jelas-jelas disebutkan dalam peraturan undang undangan khususnya pada Pasal 49 Undangundang No. 3 Tahun 2006 tentang peradilan agama;

Dalam ilmu hukum dikenal teori fiksi hukum yang menyatakan bahwa diundangkannya sebuah peraturan perundang-undangan oleh instansi yang berwenang mengandaikan semua orang mengetahui peraturan tersebut. Dan kewajiban untuk mempublikasikan peraturan yang dibuat dengan sendirinya gugur ketika peraturan tersebut resmi diundangkan oleh pemerintah. Dengan kata lain tidak ada alasan bagi pelanggar hukum untuk menyangkal dari tuduhan pelanggaran dengan alasan tidak mengetahui hukum atau peraturannya

Berdasarkan latar belakang tersebut di atas, penulis tertarik ingin mencoba meneliti dan Menganalisis Faktor Yang Mempengaruhi Tidak Ada Perkara Ekonomi Syariah Masuk Di Pengadilan Agama Singaraja”

\section{B. PEMBAHASAN}

Dalam rumusan judul artikel ini terdapat beberapa istilah, dua buah istilah di antaranya mempunyai makna khas yang memerlukan penjelasan lebih rinci agar mendapatkan pemahaman sesuai dengan maksud tulisan. Istilah tersebut Ekonomi Syariah dan Pengadilan Agama.

Istilah ekonomi syariah hanya dikenal di Indonesia, karena di negara lain istilah yang polpuler adalah ekonomi islam (Islamic economy). Secara substansial, ekonomi syariah (Islamic economy) berbeda dengan ekonomi konvensional yang berkembang dewasa ini. Perbedaan yang terpenting adalah karena ekonomi syariah terikat pada nilai-niali Islam dan ekonomi konvensional melepaskan diri dari ajaran agama, terutama sejak negara Barat berpegang pada sekularisme dan menjalankan politik sekulerisasi. ${ }^{6}$

Ekonomi Syariah adalah suatu cabang ilmu pengetahuan yang berupaya untuk memandang, menganalisis, dan akhirnya menyelesaikan permasalahan-

6 Kurshid Ahmad (eds), 1983, Studies in Islamic Economics, The Islamic Foundation Leicester, hal xiii-xvii (dikutip dari Rifyal Ka'bah 
permasalahan ekonomi dengan caracara Islam, yaitu berdasarkan atas ajaran agama Islam, yaitu Al Qur'an dan Sunnah $\mathrm{Nabi}^{7}$

Ekonomi syariah memiliki dua hal pokok yang menjadi landasan hukum sistem ekonomi syariah yaitu Al Qur'an dan Sunnah Rasulullah, hukum-hukum yang diambil dari kedua landasan pokok tersebut secara konsep dan prinsip adalah tetap (tidak dapat berubah kapanpun dan dimana saja).

\section{Pengadilan}

Agama adalah pengadilan tingkat pertama yang melaksanakan kekuasaan kehakiman di lingkungan Peradilan Agama yang berkedudukan di ibu kota kabupaten atau kota. Pengadilan Agama dibentuk dengan Keputusan Presiden $^{8}$

$$
\text { Peradilan Agama hanya }
$$

berwenang di bidang perkara tertentu saja.

Peradilan Agama adalah Peradilan Islam di Indonesia, sebab dari jenisjenis perkara yang ia boleh mengadilinya, seluruhnya adalah jenis perkara menurut agama Islam.

Dapat disimpulkan bahwa Peradilan Agama adalah salah satu dari Peradilan Negara Indonesia yang sah, yang bersifat Peradilan Khusus, yang berwenang dalam jenis perkara perdata Islam tertentu, bagi orangorang Islam di Indonesia

7 Pusat Pengkajian dan Pengembangan Ekonomi Islam (P3EI). 2012. Ekonomi Islam. Jakarta: PT Raja Grafindo Persada.hal 17

${ }^{8}$ https://id.wikipedia.org/wiki/Pengadilan_Aga ma\#cite_notesejarah_dan_Perkembangan_Ma hkamah_Syar\%E2\%80\%99iyah_di_Aceh-1

\section{EKONOMI SYARIAH}

Istilah ekonomi syariah hanya dikenal di Indonesia, karena di negara lain istilah yang polpuler adalah ekonomi islam (Islamic economy). Secara substansial, ekonomi syariah (Islamic economy) berbeda dengan ekonomi konvensional yang berkembang dewasa ini. Perbedaan yang terpenting adalah karena ekonomi syariah terikat pada nilai-niali Islam dan ekonomi konvensional melepaskan diri dari ajaran agama, terutama sejak negara Barat berpegang pada sekularisme dan menjalankan politik sekulerisasi. ${ }^{9}$ Sungguh pun demikian, tidak ada ekonomi yang bebas nilai, akan tatapi nilai dalam ekonomi konvensional adalah nilai duniawi (profane), sedangkan dalam ekonomi syariah adalah niklai ukhrawi (eternal).

Untuk memahami pengertian ekonomi syariah, sebaiknya diketengahkan terlebih dahulu pengertian ekonomi secara umum. Menpurut Paul Anthony Samuelson yang dikutip oleh Aly Masykuroh, 10 ilmu ekonomi adalah ilmu yang membicarakan tentang studi mengenai tata cara manusia dan masyarakat dalam menjatuhkan pilihan, dengan atau tanpa menggunakan sumber-

9 Kurshid Ahmad (eds), 1983, Studies in Islamic Economics, The Islamic Foundation Leicester, hal xiii-xvii (dikutip dari Rifyal Ka'bah

${ }^{10}$ Ely Masykuroh, pengantar Teori Ekonomi : pendekatan pada teoti ekonomi makro Islam, (Panoraga : STAIN Panoraga Press, 2008 hal. 10 
sumber produktif langka yang dapat mempunyai kegunaan - kegunaan alternatif, untuk memproduksikan dan mendistribusikan berbagai barang untuk dikonsumsi, baik untuk waktu sekarang maupun untuk waktu yang kana datang, untuk berbagai golongan dan kelompok masyarakat. Ilmu ekonomi juga manganalisis besarnya biaya-biaya serta keuntungan yang terjadi karena adanya perbaikan dalam pola alokasi sumber-sumber. ${ }^{11}$

Ekonomi Syariah adalah suatu cabang ilmu pengetahuan yang berupaya untuk memandang, menganalisis, dan akhirnya menyelesaikan permasalahanpermasalahan ekonomi dengan caracara Islam, yaitu berdasarkan atas ajaran agama Islam, yaitu Al Qur'an dan Sunnah Nabi ${ }^{12}$

Ekonomi syariah memiliki dua hal pokok yang menjadi landasan hukum sistem ekonomi syariah yaitu Al Qur'an dan Sunnah Rasulullah, hukum-hukum yang diambil dari kedua landasan pokok tersebut secara konsep dan prinsip adalah tetap (tidak dapat berubah kapanpun dan dimana saja).

Berikut ini beberapa pengertian Ekonomi Syariah dari beberapa sumber buku:

1. M.A. Mannan mendefinisikan ilmu ekonomi syariah sebagai suatu ilmu pengetahuan sosial yang mempelajari masalah-

11 Amran Suadi, Abdul Manan Ilmuan dan praktisi Hukum kenangan sebuah perjuangan, Jakarta Kencana 2016, hal 308-309.

12 Pusat Pengkajian dan Pengembangan Ekonomi Islam (P3EI). 2012. Ekonomi Islam. Jakarta: PT Raja Grafindo Persada, hal. 7 masalah ekonomi rakyat yang diilhami oleh nilai-nilai islam ${ }^{13}$

2. Yusuf Qardhawi. Pengertian Ekonomi Syariah merupakan ekonomi yang berdasarkan pada ketuhanan. Esensi sistem ekonomi ini bertitik tolak dari Allah, tujuan akhirnya kepada Allah, dan memanfaatkan sarana yang tidak lepas dari syari'at Allah.

3. Ziauddin Ahmad. Ekonom yang berasal dari Pakistan ini merumuskan pengertian Ekonomi Syariah merupakan upaya pengalokasian sumbersumber daya untuk memproduksi barang dan jasa sesuai petunjuk Allah SWT untuk memperoleh ridha-Nya.

4. M. Syauqi Al-Faujani. Ekonomi Syariah merupakan segala aktivitas perekonomian beserta aturan-aturannya yang didasarkan kepada pokok-pokok ajaran Islam tentang ekonomi.

5. Khursid Ahmad. Ilmu Ekonomi Syariah merupakan suatu upaya sistematis untuk mencoba memahami permasalahan ekonomi dan perilaku manusia dalam hubungannya dengan permasalahan tersebut dari sudut pandang Islam."

Tujuan Ekonomi Syariah selaras dengan tujuan dari syariat Islam itu sendiri (maqashid asy syari'ah), yaitu mencapai kebahagiaan di dunia dan akhirat (falah) melalui suatu tata kehidupan yang baik dan

13 M. A Mannan.. Ekonomi Islam: Teori dan Praktek. Jakarta, 1992 : PT. Intermasa, hal 15 
terhormat (hayyah thayyibah). Tujuan falah yang ingin dicapai oleh Ekonomi Syariah meliputi aspek mikro ataupun makro, mencakup horizon waktu dunia atau pun akhirat ${ }^{14}$.

Seorang fuqaha asal Mesir bernama Prof. Muhammad Abu Zahrah mengatakan ada tiga sasaran hukum Islam yang menunjukkan bahwa Islam diturunkan sebagai rahmat bagi seluruh umat manusia, yaitu $^{15}$ :

a. Penyucian jiwa agar setiap muslim bisa menjadi sumber kebaikan bagi masyarakat dan lingkungannya.

b. Tegaknya keadilan dalam masyarakat. Keadilan yang dimaksud mencakup aspek kehidupan di bidang hukum dan muamalah.

c. Tercapainya maslahah (merupakan puncaknya). Para ulama menyepakati bahwa maslahah yang menjadi puncak sasaran di atas mencakup lima jaminan dasar, yaitu: keselamatan keyakinan agama (al din), kesalamatan jiwa (al $n a f s)$, keselamatan akal (al aql), keselamatan keluarga dan keturunan (al nasl) dan keselamatan harta benda (al mal).

\footnotetext{
${ }^{14}$ Pusat Pengkajian dan Pengembangan Ekonomi Islam (P3EI).Op.cit hal 54

${ }^{15}$ Rahman, Afzalur.. Doktrin ekonomi Islam Jilid I. 1995 Yogyakarta: Dana Bhakti Wakaf, hal. 84
}

Pelaksanaan ekonomi syariah harus menjalankan prinsip-prinsip sebagai berikut: ${ }^{16}$

1. Berbagai sumber daya dipandang sebagai pemberian atau titipan dari Allah swt kepada manusia.

2. Islam mengakui pemilikan pribadi dalam batas-batas tertentu.

3. Kekuatan penggerak utama Ekonomi Syariah adalah kerja sama.

4. Ekonomi Syariah menolak terjadinya akumulasi kekayaan yang dikuasai oleh segelintir orang saja.

5. Ekonomi Syariah menjamin pemilikan masyarakat dan penggunaannya direncanakan untuk kepentingan banyak orang.

6. Seorang muslim harus takut kepada Allah swt dan hari penentuan di akhirat nanti.

7. Zakat harus dibayarkan atas kekayaan yang telah memenuhi batas (nisab).

8. Islam melarang riba dalam segala bentuk

Layaknya sebuah bangunan, sistem ekonomi syariah harus memiliki fondasi yang berguna sebagai landasan dan mampu menopang segala bentuk kegiatan ekonomi guna mencapai tujuan mulia. Berikut ini merupakan prinsip-prinsip dasar dalam ekonomi syariah, diantaranya adalah $:{ }^{17}$

16 Sudarsono, M.B, Hendri. 2002. Pengantar Ekonomi Mikro Islam. Yogyakarta, Ekonosia, hal. 105

17 Zainuddin Ali. 2008. Hukum Ekonomi Syariah. Jakarta: Sinar Grafika Offset 
1. Tidak melakukan penimbunan (Ihtikar). Penimbunan, dalam bahasa Arab disebut dengan alihtikar. Secara umum, ihtikar dapat diartikan sebagai tindakan pembelian barang dagangan dengan tujuan untuk menahan atau menyimpan barang tersebut dalam jangka waktu yang lama, sehingga barang tersebut dinyatakan barang langka dan berharga mahal.

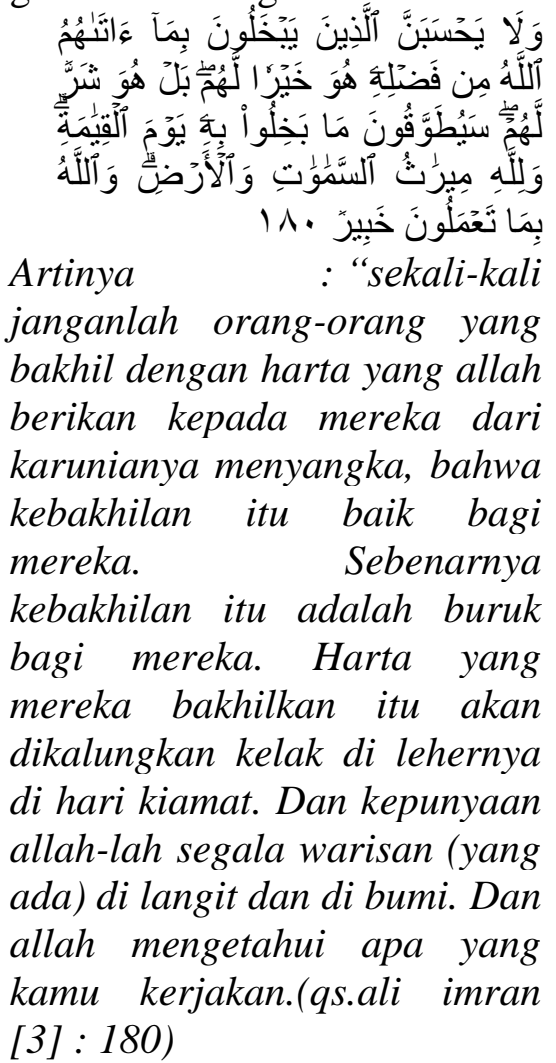

2. Tidak melakukan monopoli. Monopoli adalah kegiatan menahan keberadaan barang untuk tidak dijual atau tidak diedarkan di pasar, agar harganya menjadi mahal. Kegiatan monopoli merupakan salah satu hal yang dilarang dalam Islam, apabila monopoli diciptakan secara sengaja dengan cara menimbun barang dan menaikkan harga barang.

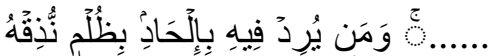

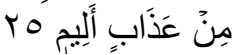

" Dan barang siapa yang bermaksud di dalamnya ( Mekkah ) melakukan kejahatan secara lalim, niscaya akan Kami rasakan kepadanya sebahagian siksa yang pedih." ( Qs al-Hajj : 25 ) 3. Menghindari jual-beli yang diharamkan. Kegiatan jual-beli yang sesuai dengan prinsip Islam, adil, halal, dan tidak merugikan salah satu pihak adalah jual-beli yang sangat diridhai oleh Allah swt. Karena sesungguhnya bahwa segala hal yang mengandung unsur kemungkaran dan kemaksiatan adalah haram hukumnya. sebagaimana

tercantum dalam Al-Qur'an surat Al baqarah ayat 168 sebagai berikut

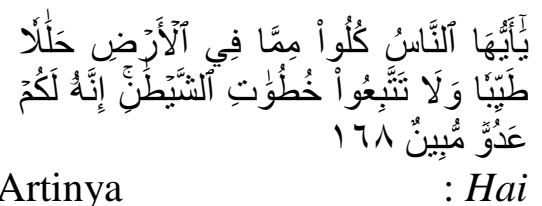
sekalian manusia, makanlah yang halal lagi baik dari apa yang terdapat di bumi dan janganlah kamu mengikuti langkah-langkah syaitan; karena sesungguhnya syaitan itu adalah musuh yang nyata bagimu Q.S. : 2 : 168
PENGADILAN
KEDUDUKAN KEWENANGANNYA

AGAMA

DAN 
Sebagaimana yang diamanatkan oleh Undang-Undang Dasar 1945 Pasal 1 Ayat (3) yang menegaskan bahwa Negara Indonesia adalah Negara hukum. Hal itu menunjukan betapa pentingnya fungsi lembaga peradilan di Indonesia. Suatu Negara dapat dikatakan sebagai Negara hukum dapat diukur dari pandangan bagaimana hukum itu diperlakukan, apakah ada sistem peradilan yang baik dan tidak memihak serta bagaimana bentukbentuk pengadilannya dalam menjalankan fungsi peradilan.

Oleh karena itu untuk mewujudkan suatu keadilan, ketertiban, kebenaran dan kepastian hukum dalam sistem penyelenggaraan hukum demi terciptanya suasana berkehidupan yang aman, tertib, dan tentram. Maka dibutuhkan adanya lembaga yang bertugas untuk menyelenggarakan kekuasaan kehakiman guna menegkan hukum dan keadilan dengan baik.

Salah satu lembaga untuk menegakan hukum dan dalam mencapai keadilan, kebenaran, ketertiban, dan kepastian hukum adalah badan-badan peradilan sebagaiman yang dimaksud dalam UU Nomor 48 Tahun 2009 tentang kekuasaan kehakiman yang masingmasing mempunyai lingkup kewenangan mengadili perkara atas sengketa dibidang tertentu dan salah satunya adalah Badan Peradilan Agama.

Dalam hal ini, Peradilan Agama hanya berwenang di bidang perdata tertentu saja dan hanya untuk orang-orang yang beragama Islam di
Indonesia. Peradilan Agama secara nyata sudah ada dan tersebar di berbagai daerah di Indonesia sejak masa sebelum kemerdekaan Republik Indonesia dengan beraneka ragam sebutan istilahnya, seperti Rapat Ulama, Raad Agama, Mahkamah Islam, Mahkamah Syara', Priesterrad, Pengadilan Paderi, Godsdients Beamte, Mohammedansche Godsdients Beamte, Kerapatan Qadli,Hof voor Islamietische Zaken, Kerapatan Qadli Besar, Mahkamah Islam Tinggi, dan sebagainya.

Pada zaman Jepang tidak banyak mengalami perubahan tetapi pada tahun 1957 yakni setelah Indonesia merdeka, ada lagi Badan Peradilan Agama yang dibentuk baru dengan sebutan Pengadilan Agama/Mahkamah Syar'iyyah dan Pengadilan Agama/ Mahkamah Syar'iyyah Provinsi

Kedudukan dan wewenang Peradilan Agama pada masa Reformasi sejak lahirnya UndangUndang Nomor 3 Tahun 2006 atas perubahan Undang-Undang Nomor 7 tahun 1989, telah membawa perubahan besar dalam penyelenggaraan Peradilan Lembaga Peradilan Agamabaik aspek organisasi, administrasi, financial, teknis peradilan, dan penambahan keweangan absolute Peradilan Agama.

Dalam Pasal 2 jo pasal 49 Undang-Undang No.3 tahun 2006 dinyatakan bahwa, Peradilan Agama merupakan salah satu badan peradilan pelaku kekuasaan kehakiman untuk menyelenggarakan penegakan hukum dan keadilan dalam perkara tertentu antara orang-orang yang beragama 
Islam dibidang perkawinan, kewarisan, wasiat, hibah, wakaf, zakat, infaq, shadaqoh dan ekonomi syariah.

Dalam penjelasan Pasal 49 UU No.3 tahun 2006 ditegaskan bahwa, yang dimaksud "antara orang-orang yang beragama Islam" adalah termasuk orang atau badan hukum yang dengan sendirinya menundukkan diri dengan suka rela kepada hukum Islam mengenai hal-hal yang menjadi kewenangan Peradilan Agama sesuai ketentuan pasal ini.

Dari penjelasan Pasal 49 tersebut, maka seluruh nasabah lembaga keuangan dan lembaga pembiayaan syariah, atau bank konvensional yang membuka unit usaha syariah, dengan sendirinya terikat dengan ketentuan ekonomi syariah baik dalam pelaksanaan akad maupun dalam penyelesaian perselisihan.

Dalam melakukan hubungan hukum, bisa saja terjadi konflik atau sengketa keperdataan, seperti adanya wan prestasi ( cedera janji ) atau perbuatan melawan hukum dari salah satu pihak, dan jika terjadi perselisihan atau sengketa dalam perbankan syariah terutama mengenai pelaksanaan akad atau perjanjian yang telah disepakati, baik antar sesama bank syariah atau antara pihak bank dengan nasabahnya, maka hal ini akan berakibat hukum terhadap status barang jaminan , upaya hukum bagi kedua belah pihak dalam menyelesaikan perselisihannya dan pelaksanaan terhadap obyek sengketa.

Pada dasarnya perselisihan dalam bidang bisnis dan keperdataan, bisa diselesaikan diluar pengadilan seperti perdamaian ( al-sulh ) , arbitrase
( al-tahkim) yang dalam UU No.30 tahun 1999 disebut negosiasi, konsultasi, mediasi, dan arbitrase, atau dapat pula melalui lembaga peradilan (al-qodlo). Para pihak diberi keleluasan dalam menyelesaikan perselisihan mereka dengan cara yang dianggap lebih tepat dan menguntungkan dengan berpedoman kepada perjanjian yang telah dibuat dan peraturan perundang-undangan yang berlaku.

Penyelesaian sengketa melalui pengadilan ( litigasi ) sekalipun terkadang dipandang terlalu menguras tenaga, biaya dan memakan waktu yang cukup lama, namun harus diakui bahwa penyelesaian sengketa melalui lembaga peradilan (litigasi) lebih memberikan kepastian hukum dan keadilan, dengan pertimbangan:

1. Pengadilan sebagai bagian dari sistem pemisahan atau pembagian kekuasaan diantara badan-badan penyelenggara Negara. Kekuasaan kehakiman yang merdeka untuk menjamin dan melindungi kebebasan indifidu,

2. Kekuasaan kehakiman yang merdeka diperlukan untuk mencegah penyelenggara pemerintahan bertindak tak semena-mena dan menindas.

3. kekuasaan kehakiman yang merdeka diperlukan untuk dapat menilai keabsahan secara hukum tindakan pemerintahan atau suatu peraturan perundangundangan sehingga sistem 
hukum dijalankan dan ditegakkan dengan baik ${ }^{18}$

\section{ASAS HUKUM PENGADILAN PASIF}

Asas hukum (rechtsbeginsel) adalah pokok pikiran yang bersifat umum yang menjadi latar belakang dari peraturan hukum yang konkret (hukum positif). Prof. Dr. Satjipto Rahardjo, S.H. mengatakan asas hukum adalah jiwanya peraturan hukum, karena ia merupakan dasar lahirnya peraturan hukum,ialah ratio legisnya peraturan

Hakim Bersifat Menunggu

a. Asas ini berarti bahwa inisiatif berperkara di pengadilan ada pada pihak-pihak yang berkepentingan dan bukan dilakukan oleh hakim (inde ne proeedat ex officio). Hakim hanya besikap menunggu datangnya tuntutan hak yang diajukan kepadanya. Akan adanya proses atau tidak, ada tuntutan hak atau tidak diserahkan sepenuhnya kepada pihak-pihak yang berkepentingan. Kalau sudah ada tuntutan yang menyelenggarakan proses adalah Negara.

b. Hal ini karena hukum acara perdata hanya mengatur caracara bagaimana para pihak mempertahankan kepentingan pribadinya. Seorang hakim tidak boleh menolak untuk memeriksa

18 Bagir Manan, Kekuasaan Kehakiman Republik Indonesia, ( Bandung : Pusat penerbitan Universitas Islam Bandung, 1995 ) hal.6 dan mengadili perkara yang diajukan kepadanya, dengan alasan bahwa hukum tidak atau kurang jelas (Pasal 16 ayat (1) UU No. 4 tahun 2004). Dalam hal ini hakim dianggap tahu akan hukumnya (ius curia novit). Apabila hukum tertulis tidak ditemukan, maka hakim wajib menggali, mengikiti dan memahami nilai-nilai hukum dan rasa keadilan yang hidup dalam masyarakat (Pasal 28 ayat (2) UU No. 4 tahun 2004)

1. Hakim Bersikap Pasif

i. Maksud hakim bersikap pasif adalah hakim tidak menentukan ruang lingkup atau luas pokok sengketa yang diajukan kepadanya,tapi yang menentukan adalah para pihak sendiri. Hakim tidak boleh menambah atau menguranginya. Hakim hanya membantu para pencari keadilan dan berusaha mengatasi segala hambatan dan rintangan untuk dapat tercapainya peradilan yang sederhana, cepat dan biaya ringan (Pasal 5 ayat (2) UU No. 5 tahun 2004).

ii. Hakim harus mengadili seluruh bagian gugatan, tetapi hakim dilarang menjatuhkan putusan atas perkara yang tidak dituntut atau mengabulkan lebih daripada yang dituntut (Pasal 178 ayat 2,3 HIR/189 ayat 2, dan $3 \mathrm{Rbg}$ ).

iii. Namun bukan berarti hakim tidak berbuat apa-apa. Selaku pimpinan sidang hakim harus aktif memimpin jalannya persidangan sehingga berjalan lancar. Hakimlah yang 


\begin{abstract}
menentukan pemanggilan, menetapkan hari persidangan serta memerintahkan supaya alat bukti yang diperlukan disampaikan dalam persidangan. Hakim juga berwenang memberikan nasihat, mengupayakan perdamaian, menunjukkan upaya-upaya hukum dan memberikan keterangan kepada pihak-pihak yang berperkara (Pasal 132 HIR/156 Rbg). Karena itu sering dikatakan dalam sistem HIR adalah hakim aktif, sedangkan dalam sistem Rv hakim pasif. Karena Rv mewajibkan para pihak mewakilkan kepada orang lain (procureur) dalam beracara dimuka pengadilan.
\end{abstract}

\section{KABUPATEN BULELENG}

Kabupaten Buleleng adalah sebuah kabupaten di provinsi Bali. Ibu kotanya ialah Singaraja. Buleleng berbatasan dengan Laut Jawa di sebelah utara, Kabupaten Jembrana di sebelah barat, Kabupaten Karangasem di sebelah timur dan Kabupaten

Bangli, Tabanan serta Badung di sebelah selatan.

Singaraja adalah Kota Istana Raja Buleleng yang dibangun/didirikan pada tanggal 30 Maret 1604 oleh I Gusti Ngurah Panji Sakti (Raja Buleleng/Bupati Buleleng yang pertama). Dinamakan Singaraja karena untuk mengenang keperwiraan sang Raja yang laksana Singa dalam pertempuran. Singaraja yang merupakan Ibu Kota Kabupaten Buleleng terletak di Ujung Utara Pulau
Dewata/Pulau Bali/Propinsi Bali, Kabupaten Buleleng adalah wilayah yang terluas di Propinsi Bali, dibanding kabupatenkabupaten lainnya (luas wilayah Kabupaten Buleleng satu per empat bahagian Propinsi Bali).

Buleleng dibagi kepada 9 kecamatan dan 148 desa. Kecamatankecamatannya adalah:

Gerokgak

Seririt

Busung Biu

Banjar

Buleleng

Sukasada

Sawan

Kubutambahan

Tejakula

Bila di lihat dari besaran agama yang paling banyak dianut, sebagain besar penduduk provinsi Bali memeluk agama Hindu, yang berikutnya adalah Agama Islam, Kristen, Katolik dan Budha. Agama Hindu menjadi mayoritas di semua kabupaten dan kota, sedangkan Agama Islam dengan jumlah besar di Provinsi ini ada di Kota Denpasar, Kabupaten Badung, Jembrana dan Buleleng , Agama Kristen, Katolik dan Budha dengan populasi besar ada di Kota Denpasar, dan Kabupaten Badung, Berikut data di sajikan dalam bentuk tabel untuk setiap kota dan kabuaten di provinsi dimaksud.

Dalam pengambilan data dimaksud, dari total jumlah penduduk yang didata, di temukan data yang tidak terjawab sebesar 1 Jiwa dan tidak ditanyakan sebesar 5.513 jiwa, dan lainnya sebesar 282 jiwa. Maka ketiga jumlah itu jika ditambahkan dengan jumlah penduduk yang terdata 
pada tabel, yang ditemukan adalah jumlah total penduduk dalam provinsi di maksud. Adapun pada kolom jumlah dalam tabel, untuk sub jumlah pada tiap kabupaten dan kota, adalah penjumlahan dari besaran yang ada pada kolom-kolom Agama di sampingnya, sedangkan selisih kurang dari jumlah tersebut adalah mereka yang masuk pada kategori data tidak terjawab dan tidak terdata seta lainlain. ${ }^{19}$

\section{Pengadilan Agama Singaraja}

Peradilan Agama Singaraja sama seperti Pengadilan Agama lainnya di Indonesia. Pengadilan Agama pada umumnya telah ada di Nusantara jauh sejak zaman masa penjajahan Belanda.Bahkan menurut pakar sejarah peradilan, ia teah ada sejak Islam masuk ke Indonesia, yaitu melalui tahkim. Perubahan zaman telah membawa pasang surut perkembanganya hingga Indonesia merdeka. Ia disyahkan sebagai bagian dari sistem peradilan dengan UU No. 7 tahun 1989 tentang Peradilan Agama. Walaupun mengalami berbagai tantangan, namun PA masih bisa eksis hingga saat ini. Beralihnya PA menjadi bagian dari Mahkamah Agung memiliki dapak negatif dan positif. Dampak negatifnya adalah ia tidak lagi menjadi kewenangan Kementerian Agama sebagai induknya, sementara dampak positifnya adalah secara langsung PA telah diakui keberadaannya sebagai bagian dari lembaga

${ }^{19}$ www.sp2010.go.id. peradilan di Indonesia. Saat ini kewenangan Pengadilan Agama tidak hanya dalam masalah Nikah, Thalak, cerai dan rujuk saja. Ia juga mengadili masalah persengketaan ekonomi syariah di Indonesia. Berkembangnya ekonomi syariah menjadikan PA semakin memiliki prospek di masa yang akan datang.

Sebagai Badan Pelaksana Kekuasaan Kehakiman bagi rakyat pencari keadilan ialah menerima, memeriksa dan memutuskan setiap perkara yang diajukan kepadanya, termasuk didalamnya menyelesaikan perkara voluntair.

Peradilan Agama juga adalah salah satu diantara 3 Peradilan Khusus di Indonesia. Dikatakan Peradilan Khusus karena Peradilan Agama mengadili perkara-perkara perdata tertentu dan mengenai golongan rakyat tertentu. Dalam struktur Organisasi Peradilan Agama, ada Pengadilan Agama dan Pengadilan Tinggi Agama yang secara langsung bersentuhan dengan penyelesaian perkara di tingkat pertama dan banding sebagai manifestasi dari fungsi kekuasaan kehakiman. Kekuasaan kehakiman di lingkungan peradilan agama dilaksanakan oleh Pengadilan Agama dan Pengadilan Tinggi Agama.

Tugas-tugas lain Pengadilan Agama ialah :

1.

Memberikan

keterangan, pertimbangan dan nasehat tentang Hukum Islam kepada instansi Pemerintah didaerah hukumnya apabila diminta.

2. dan rukyatul hilal.
Melaksanakan hisab Melal. 
3.

Melaksanakan tugastugas lain pelayanan seperti pelayanan riset/penelitian, pengawasan terhadap penasehat hukum dan sebagainya.

4.

permohonan pembagian harta

peninggalan diluar sengketa antara orang-orang yang beragama Islam.

Dengan demikian, Pengadilan Agama bertugas dan berwenang untuk menyelesaikan semua masalah dan sengketa yang termasuk di bidang perkawinan, kewarisan, perwakafan, hibah, infaq, shadaqah, dan ekonomi syariah.

\section{Penanganan Perkara}

Keadaan perkara yang ditangani Pengadilan Agama Singaraja tahun 2017 baik perkara yang masuk pada tahun 2017 maupun sisa perkara tahun sebelumnya yang masih belum terselesaikan. Keadaan perkara yang dimaksud meliputi perkara yang masuk, jenis perkara, perkara putus, minutasi, penerbitan akta cerai sampai upaya hukum para pihak atas putusan Pengadilan Agama Singaraja yang dimulai pada tanggal 01 Januari 2017 sampai dengan tanggal 31 Desember 2017;

Prosedur penerimaan perkara tingkat pertama (perkara gugatan dan permohonan), perlawanan (verzet), permohonan banding, kasasi dan peninjauan kembali (PK) serta permohonan eksekusi dilakukan dengan sistem meja, yakni Meja Pertama (termasuk didalamnya petugas Kasir) Meja Kedua dan Meja ketiga

Prosedur penerimaan perkara melalui meja I dan II, sesuai Bindalmin dalam pelaksanaan menjadi tanggung jawab Panitera Muda Gugatan dan
Panitera Muda Permohonan, demikian juga untuk Petugas Meja III adalah

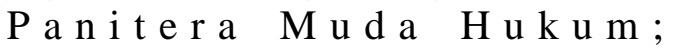
Selama tahun 2017 , pelaksanaan administrasi perkara telah berjalan sebagaimana mestinya sesuai Pola Bindalmin. Pendaftaran dilakukan melalui Meja I, PMH dibuat tepat waktu begitu juga PHS. Pendaftaran, pencatatan, pembagian perkara, penentuan hari sidang, pemanggilan atau pemberitahuan isi putusan semua berjalan dengan menggunakan formulir dan instrumen yang berbasis court calender seperti ditentukan dalam Pola Bindalmin. Pemberkasan perkara (minutasi)dilakukan tetap waktu, juga Pengadilan Agama Singaraja selama tahun 2017 menangani sebanyak 200 perkara dimana sebanyak 170 perkara adalah perkara baru (diterima selama tahun 2017) yang terdiri dari 126 perkara gugatan (terdiri dari 38 perkara Cerai Talak, 87 perkara Cerai Gugat dan 1 perkara Gugatan Waris) dan 44 perkara permohonan (terdiri dari 38 perkara Itsbat Nikah, 3 perkara Dispensasi Kawin, 1 perkara Penetapan Ahli Waris, 1 perkara Wali Adhol dan 1 perkara Perwalian) sedangkan sebanyak 30 perkara adalah sisa/tundaan perkara tahun 2016 dimana 29 perkara adalah perkara Gugatan dan 1 perkara permohonan.

Tahun 2017, Pengadilan Agama Singaraja menangani sebanyak 200 perkara dimana sebanyak 170 perkara adalah perkara baru (diterima selama tahun 2017) yang terdiri dari 126 perkara gugatan dan 44 perkara permohonan sedangkan sebanyak 30 perkara adalah sisa/tundaan perkara 
tahun 2016 dimana 29 perkara adalah perkara gugatan dan 1 perkara permohonan. Hal ini menunjukkan bahwa Pengadilan Agama Singaraja di tahun 2017 ini mengalami peningkatan dalam menangani perkara sebanyak 9 perkara atau 4,5\%.Pada tahun 2017, dari 200 perkara tersebut, sebanyak 134 perkara gugatan telah diputus, sedangkan sebanyak 21 perkara gugatan masih belum diputus dan perkara permohonan sebanyak 44 perkara telah diputus dan sisanya 1 perkara masih belum diputus. Pada tahun 2016, dari 191 perkara tersebut, sebanyak 121 perkara gugatan, telah diputus, sedangkan sebanyak 29 perkara gugatan masih belum diputus dan dari 41 perkara permohonan sebanyak 40 perkara telah diputus dan sisa nya 1 perkara masih belum diputus. Penanganan perkara yang telah diputus tahun 2017 mengalami peningkatan dibanding dengan tahun 2016 hal ini juga berbanding lurus dengan penanganan perkara yang telah diputus tahun 2017 mengalami peningkatan dari tahun 2016.

Sementara hasil wawancara dengan Bapak Ahmad Basirudin, SH. Selaku Panitera Muda Hukum Pengadilan Agama Singaraja untuk perkara sengketa ekonomi syariah sejak diundangkannya Undang-undang No. 3 tahun 2006 yang merupakan perubahan atas Undang Undang Nomor 7 tahun 1989 tentang peradilan Agama sampai saat ini belum ada perkara ekonomi syariah masuk di pengadilan Agama Singaraja hal ini bisa dikarenakan memang belum ada sengketa di Perbankan syariahhnya meskipun di kabupaten Bouleleng ini sudah ada 2 (dua) perbangkan hsyariah yakni Bank Syariah Mandiri dan Bank BNI Syariah atau bisa jadi masyarakat Singaraja yang tidak tau penyelesaiannya apabila terjadi sengkete dengan perbankan syaria.

Menurut Panitera Muda Hukum Pengadilan Agama Singaraja perlu adanya penyuluhan dan pengedukasian terhadap masyarakat perihal tersebut, namun Pengadilan Agama Singaraja tidak berwenang untuk mengadakan penyuluhan tersebut karena Pengadilan Agama hanya bersifat pasif, semestinya dari pemerintah daerah setempat yang berinisiatif untuk mengadakan penyuluhun perihal kesadaran hukum, tentunya bekerja sama dengan Pengadilan Agama Singaraja sebagai salah satu narassumbernya.

Disamping itu juga biasanya yang akan melakukan kegiatan transaksi atau dengan akad syariah kebanyakan umat Islam, sementara disisi lain umat Islam di Kabupaten Bueleleng termasuk minoritas hanya mencapai $13 \%$ dari seluruh penduduk kabupaten Buleleng sehingga hal yang sangat wajar apabila penanganan perkara di Pengadilan Agama Singaraja relatif sedikit karna hal tersebut.

\section{KESIMPULAN}

Berdasarkan uraian tersebut diatas penulis dapat mengambil kesimpulan sebagai berikut :

1. Faktor yang mempengaruhi tidak adanya perkara ekonomi syariah di Pengadilan Agam Singaraja

a. Tidak ada pihak yang memperkaraakan sengketa 
ekonomi syariah ke Pengadilan Agama Singaraja, hal ini bisa terjadi karena memang tidak ada sengketa antara nasabah dengan pihak perbankan ;

b. Karena faktor minoritas

2. Kewenangan Pengadilan Agama Singaraja sama seperti kewenangan pengadilan agama pada umunya di Indonesia yaitu dalam kewenangannya Pengadilan Agama mempunyai dua kewenangan yaitu:

3. Kewenangan Mutlak (Absolute Competensi) yaitu kewenangan yang menyangkut kekuasaan mutlak untuk mengadili suatu perkara dan yang menjadi kewenangan absolute Pengadilan Agama adalah: Menerima, memeriksa, mengadili dan memutus serta menyelesaikan perkara antara orang-orang yang beragama Islam dalam bidang:

a. Perkawinan

\section{DAFTAR PUSTAKA}

Adiwarman A. Karim, Perkembangan Ekonomi Syariah dan Potensi Sengketanya di Peradilan Agama Majalah Peradilan Agama, Edisi 3, Des 2013Feb 2014, Penerbit Dirjen Badilag MA-RI, 2013.

Afdol, Legislasi Hukum Islam di Indonesia, (Surabaya: Airlangga University Press, 2006).

Amran Suadi, Abdul Manan Ilmuan dan praktisi Hukum kenangan b. Waris

c. Wasiat

d. Hibah

e. Wakaf

f. Zakat

g. InfaqShadaqoh

h. Ekonomi Syari'ah

4. Kewenangan

Relatif (Relative

Competensi) yaitu kewenangan mengadili suatu perkara yang menyangkut wilayah/daerah hukum (yurisdiksi).

5. Peran Pengadilan Agama Singaraja dalam menyelesaikan perkara ekonomi syariah bersifat pasif, pengadilan Agama Singaraja hanya menunggu sampai adanya perkara ekonomi syariah itu masuk ke Pengadilan Agama Singaraja. Dan apabila perkara tersebut masuk maka Pengaduilan Agama Singaraja harus menyelsaikannya

sebuah perjuangan, Jakarta Kencana 2016.

Bagir Manan, Kekuasaan Kehakiman Republik Indonesia, (Bandung : Pusat penerbitan Universitas Islam Bandung, 1995).

Didi Fahrudin, Metode Penelitian untuk ilmu ekonomi, manajemen dan akuntasi dalam teori dan praktek (Surabaya: PPS UM Surabaya, Cet. Ke II, 2012).

Ely Masykuroh, pengantar Teori Ekonomi : pendekatan pada teoti ekonomi makro Islam, 
(Panoraga : STAIN Panoraga Press, 2008).

https://id.wikipedia.org/wiki/Pengadila n_Agama\#cite_notesejarah_da n_Perkembangan_Mahkamah_ Syar\%E2\%80\%99iyah_di_Ace h-1

Kurshid Ahmad (eds), 1983, Studies in Islamic Economics, The Islamic Foundation Leicester, hal xiii-xvii (dikutip dari Rifyal Ka'bah

M. A Mannan.. Ekonomi Islam: Teori dan Praktek. Jakarta, 1992 : PT. Intermasa.

Mardani, Hukum Acara Peradilan Agama, (Jakarta: Sinar Grafika, 2007).

Mohammad Daud Ali, Lembagalembaga Islam di Indonesia, (Jakarta: Raja Grafindo, 1995).

Muhammad Syafi'i Antonio, Bank Syari'ah, Cet. 1, Gema Insani, Jakarta, 2001.

Pusat Pengkajian dan Pengembangan Ekonomi Islam (P3EI). 2012. Ekonomi Islam. Jakarta: PT Raja Grafindo Persada.

Rahman, Afzalur.. Doktrin ekonomi Islam Jilid I. 1995Yogyakarta: Dana Bhakti Wakaf,

Sudarsono, M.B, Hendri. 2002. Pengantar Ekonomi Mikro Islam. Yogyakarta, Ekonosia,

Undang-undang Nomor 3 tahun 2006 Tentang Perubahan atas Undang-Undang Nomor 7 Tahun 1989 Tentang Peradilan Agama

V. Wiratna Sujarweni, Metode Penelitian lengkap, praktis dan mudah dipahami, Pustaka Baru press 2014,.

www.sp2010.go.id.

Zainuddin Ali. 2008. Hukum Ekonomi Syariah. Jakarta: Sinar Grafika Offset 